\title{
Virtual Traveling as a New Innovation in the Tourism Sector
}

\author{
Terasuci Salona ${ }^{1}$ Septia Winduwati $1^{*}$ \\ ${ }^{1}$ Communication Science, Universitas Tarumanagara, Jakarta 11440, Indonesia. \\ *Corresponding author. Email: septiaw@fikom.untar.ac.id
}

\begin{abstract}
The emergence of the Covid-19 pandemic from the beginning of 2020 has had many impacts, one of which is the tourism sector. On the other hand, the advancement of modern technology has led to new innovations in the tourism sector called virtual traveling. The technology used is the internet, gadgets / computers, and virtual reality. The theoretical basis of this research is technological determinism, computer mediated communication (CMC), and visual culture. This study uses a qualitative research approach with data collection methods through interviews, literature study, and documentation. This research focuses on the experiences gained by both tourists and travel agents from virtual traveling. These findings indicate that virtual traveling is a technological innovation in the tourism sector that provides users with a special experience, namely tourists in the form of virtual travel through virtual reality facilities. In addition, it encourages the formation of a new community of virtual traveling service users.
\end{abstract}

Keywords: Computer-Mediated Communication, cyber space, technological determinism, virtual traveling, visual culture

\section{INTRODUCTION}

The presence of the corona disease 2019 virus or better known as Covid-19 has shaken the world. With a tremendous impact in various aspects of life in almost all corners of the world. The impact of the Covid-19 outbreak was very pronounced, especially in the aviation and tourism industry. Based on data from the Central Statistics Agency (BPS), in the August 2020 period, tourist visits from various countries who came to Indonesia decreased dramatically. This decrease reached $89.22 \%$, from 1.53 million tourists in August 2019 to 164,970 tourists in August 2020. When compared to July 2020, the number of tourist arrivals in August 2020 had increased by $4.45 \%$. (BPS, 2020)

The impact of the Covid-19 outbreak was very pronounced, especially in the aviation and tourism industry. The Ministry of Transportation of the Republic of Indonesia noted that Covid-19 has disabled at least 12,703 flights at 15 Indonesian airports that have been canceled from January to March 2020, with details of 11,680 domestic flights and 1,023 international flights. This has clearly led to a decline in foreign tourists to 7 thousand tourists per day. "The impact of the Covid-19 virus on the tourism sector causes Indonesia to experience losses of up to US \$ 500 million per month or Rp. 7 trillion," said the Coordinating Minister for Maritime Affairs and Investment. The figure for lost revenue in the aviation sector reached more than 300 billion rupiah due to cancellations and a reduction in foreign tourists. (Education, 2020)

In the tourism business sector, travel agents and tourism entrepreneurs have found an innovation in meeting the entertainment needs of their consumers in the PSBB situation. Enough with a gadget equipped with internet quota, visitors can enjoy online travel. With a variety of destinations and tourist destinations as well as cultural values that visitors can learn from, travel agents offer different offers. With virtual traveling, travel agents hope to address the entertainment needs of consumers or people whose vacation activities are hindered by the Covid-19 Pandemic.

Based on the background of the problems that have been described, the formulation of the problem in this study is how the virtual meaning of tourism is experienced by tourists. This research was conducted with the intention of knowing how the experiences gained by tourists after participating in virtual traveling.

\section{BACKGROUND}

The main framework used in this study is the determinism of communication technology. Marshall McLuhan's determinant of technology (in Febriana, 2018) departs from the assumption that technology is a force and key in regulating society. This understanding can be interpreted that materialistic technology has formed a condition in the social structure. The media in various forms have expanded and strengthened their influence not only to facilitate work but also to individual thought and action. What is conveyed by the media and accepted by individuals will greatly affect the lives of individuals. The more active in using the media, the individual will become very dependent. 
Furthermore, the determinism of communication technology decreases in Computer Mediated Communication (CMC). This theory departs from the basic theory of SIP which states that the message formed by the sender of the message has been shaped in such a way as to achieve certain communication goals. The purpose of communication is certainly beneficial both socially and in other aspects in order to attract attention in the message recipient or the intended audience.

The development of CMC has formed a new culture called visual culture. Visual culture does not depend on images alone, but the tendency to describe or visualize the existence of Mirzoeff 2002: 6. In other words, visual culture is something that can "visualize" something, whether it is something that is visible or not. This understanding is based on the concept of Heidegger 1977 "The world picture does not change from an earlier medieval one into a modern one, but rather the fact that the world becomes picture at all is what distinguishes the essence of the modern age". The realization in the modern concept of visual culture tends to visualize an existence / existence and does not have dependence on a form or image visually. The visualization of the globalization era makes a significant difference between the visual culture of the modern era and the visual culture of the middle-ages with its general and not specific characteristics (Tarifu, 2019).

\section{METHODS}

Researchers used a qualitative research approach with phenomenological research methods, namely understanding the meaning or meaning of an event or phenomenon that occurred and associated it with ordinary individuals in certain situations and conditions. The data collection technique that the researchers used was interviewing the informants in order to obtain information about the meaning obtained by tourists and also the travel agent. And supported by documentation study and literature study to complement and perfect this research. The data analysis technique used by the researchers was data reduction, data presentation, and conclusion drawing and verification. The data validity technique uses the source triangulation technique which refers to the results of interviews, literature studies and documents in collecting data.

\section{FINDINGS AND DISCUSSIONS}

Virtual traveling is an example of the development of Information Communication Technology (ICT). At first this concept originated from a study on Virtual Travel Community (VTC) which focused on groups of individuals who are tourists who communicate and build relationships through Computer Mediated Communication without distance restrictions (Nugraha, 2020). Then VTC has developed in communication studies that focus on consumer behavior from tourists both in terms of information, decision making, and sharing experiences with one another (Setyanto \& Winduwati, 2018). VTC also contributes to building relationships between residents of the city or destination and tourists who take virtual trips. From the above statement, it can be concluded that the meaning of virtual traveling is a form of communication with the aim of fulfilling information and entertainment needs using CMC technology.

In this study, the travel agent that was used as an informant was Whatravel. The marketing media used by Whatravel for this program are Instagram social media, twitter and company websites. This virtual traveling program is free of charge, in other words tourists pay freely. The media used as the main support for virtual traveling and live virtual traveling is zoom.

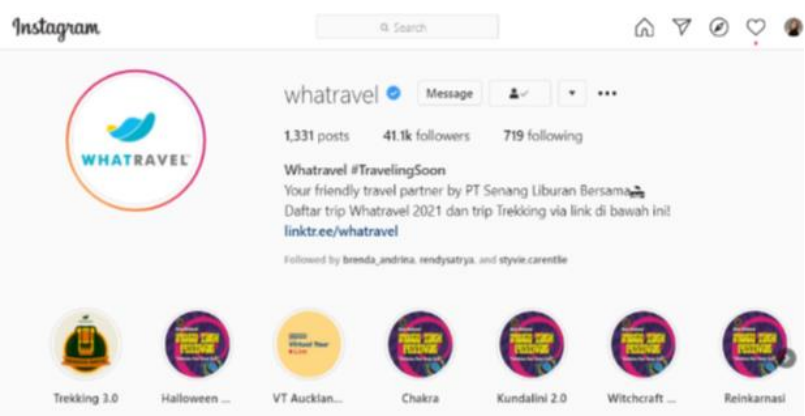

Figure 1 Whatravel's Profile in Instagram

Having 41,100 followers, Whatravel collaborates with PT Happy Holidays Together. Not only holding a virtual tour concept during a pandemic, Whatravel also holds various unique activities such as online Halloween parties. Besides that, another interesting concept is about spiritual journeys such as knowledge of kundalini and reincarnation, which are one of the prominent icons of Whatravel. Whatravel believes in these unique concepts of activity eliminates boredom and new information that is of interest to tourists.

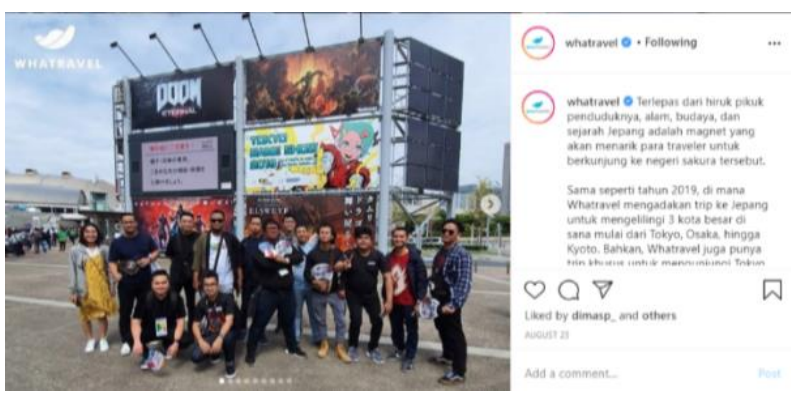

Figure 2 Tokyo Games Show 2019.

Whatravel packs it in a special travel form to visit the Tokyo Game Show in 2020. Touring 3 major cities in Japan, namely Tokyo, Osaka, and Kyoto. The 2019 Tokyo Games Show documentation is used as material or virtual travel content in the midst of the Covid-19 pandemic to remember memories in Japan together. 


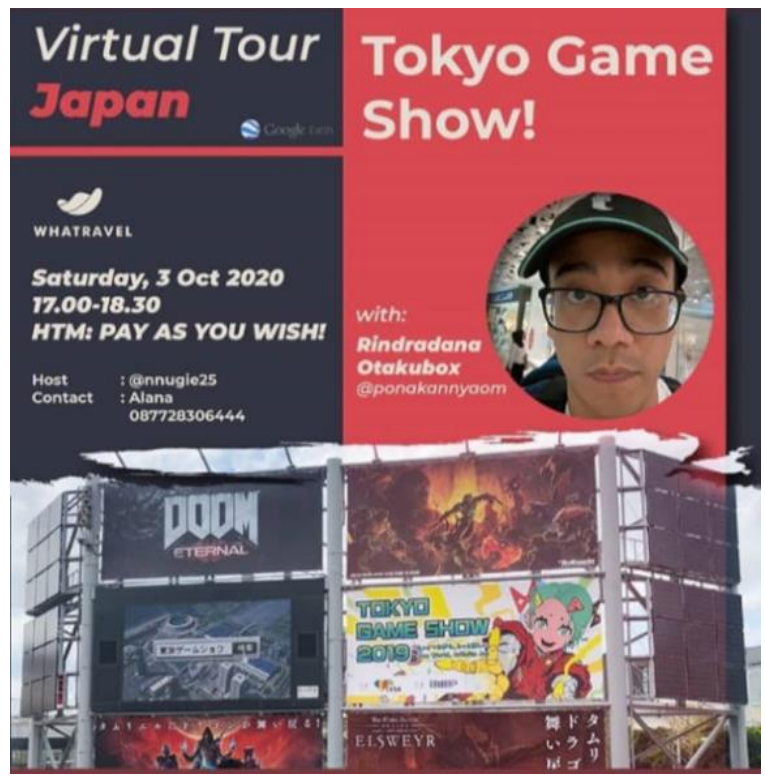

Figure 3 E-poster documentation of virtual traveling activities

Virtual traveling which will be held on October 3, 2020, from 17.00-18.30 WIB. With 50 tourists participating, you only need to pay for join at a price not determined by Whatravel. This poster is a publication through Whatravel's Instagram social media.

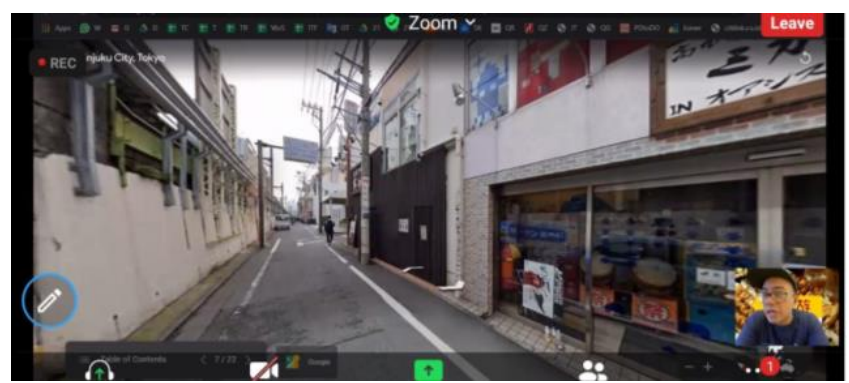

Figure 4 Documentation when virtual traveling to Japan

The Zoom application is considered the most effective choice for use in virtual traveling. In addition, with the help of google earth, it displays the location in the form of an image with GPS. As additional information, the host provides information and experiences while in Tokyo and then provides an overview through this photo documentation so that tourists can get a clear visual picture.

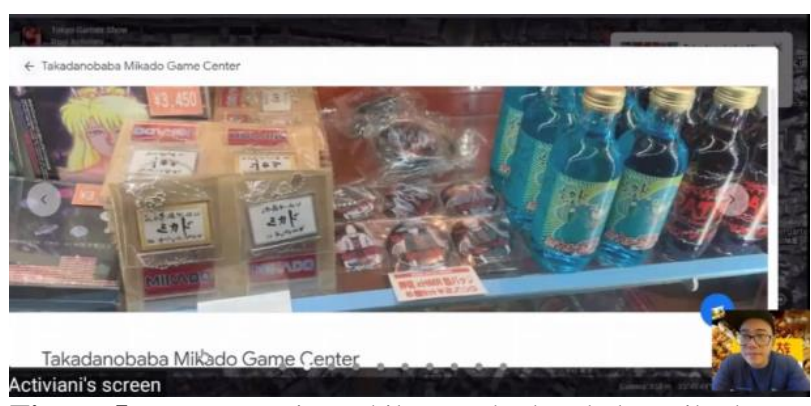

Figure 5 Documentation while at Takadanobaba Mikado
Host informs about game shopping center in Japan. The content comes from the documentation when the host visited Japan. This place was visited during the 2019 Tokyo Game Show.

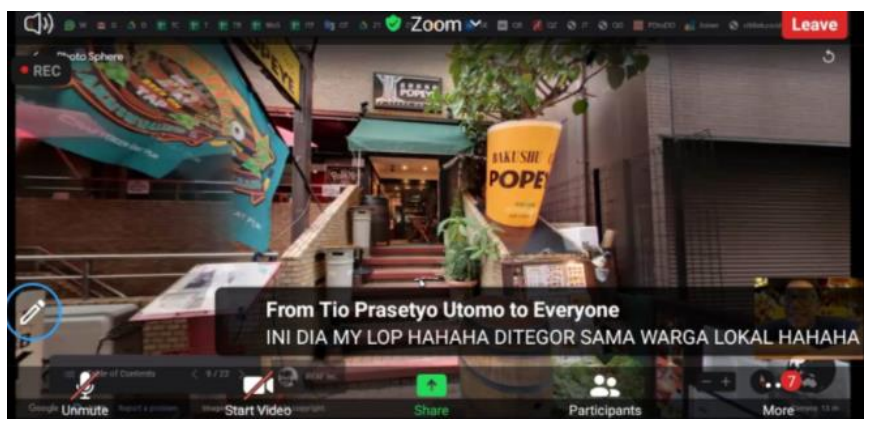

Figure 6 Documentation of Popeye Café, Tokyo

The host invites tourists to see a café in downtown Tokyo. This is a recommended place when tourists come to Japan with friends. In addition, interactions via chat also run smoothly, tourists are actively commenting and asking questions via chat.

\subsection{Informants' understanding of the concept of virtual traveling}

Based on the results of an interview with Sinta Paramita, virtual traveling is a tourism activity that relies on technology that is done online. There are differences in the concept of a vacation that is done virtually by walking in person. This is because humans have five senses that are used to capture new experiences, including the atmosphere. Traveling online is one of the new phenomena that can increase the excitement of travel during the Covid-19 pandemic. Various creatives are used by travel agents in order to build and liven up a vacation atmosphere even though it is only a visual one.

Virtual traveling in its form can be divided into two, namely virtual traveling and live virtual traveling. The two are only differentiated based on the form of content presented to consumers or tourists. Virtual traveling is usually served with google earth, videos, or photos presented in online meeting rooms with share screens. The characteristic of virtual traveling is that the moderator is not in the location or place that is the destination. The difference with live virtual traveling is that videos and images and Google Earth become supporting documents when virtual traveling takes place. Its main characteristic is that the moderator or presenter is directly at the location that becomes a tourist place or destination. Through a live broadcast, tourists can comment directly or ask questions directly. In addition, they can also directly ask local residents or the moderator could be a local resident of the place. 


\subsection{Integration of the use of digital communication technology in virtual traveling}

In the midst of the Covid-19 pandemic, it encourages every individual to adapt and integrate with communication technology. Virtual is one of the most influential trends when all are faced with problems related to limited space, like today. The existence of virtual traveling shows that individuals are integrated in terms of meeting their needs. Entertainment and information needs are one of the main things individuals use communication technology. In this case, it can be concluded that tourists who join virtual traveling have more desires and become more active.

\subsection{The advantages of virtual traveling for virtual tour operators}

In the tourism sector, virtual traveling also provides several advantages for both organizers and tourists. The first advantage is that it eliminates the limitation in quantity. The supporting components of communication technology such as the internet have provided opportunities for many tourists to join and visit a place at the same moment. If the offline tour has a limited number of visitors, then in virtual traveling this is not a problem. When tourists connect to the internet with supporting gadgets, they will easily become tourists.

The second advantage is the opportunity for tourists to enjoy destinations that have limited access or are not open to the public. Based on this statement, virtual traveling is an alternative for traveling with "unusual" destinations. For example, when organizers toured a royal cemetery that was not open to many people.

The last advantage of virtual traveling is that communication messages through virtual traveling are communication messages that are plural in nature. In other words, all tourists who take part in virtual traveling get the same portion of information. If on offline roads that get messages clearly are those in the front row, virtual traveling gives messages with the same clarity of messages. In other words, virtual traveling makes tourists focus on one object conveyed by the host, in contrast to when traveling offline tourists have different intentions or interests because of their unlimited space. This is one of the characteristics of the theory of Computer Mediated Communication (CMC), the message received will be more in accordance with the communication objectives of the sender of the message. This is because the CMC characters are asynchronous and hyperpersonal communication, the sender of the message has the opportunity to build a communication strategy and shape and construct messages to match the expectations of the sender of the message.

\subsection{The meaning of tourism virtually for tourists}

Based on the views and opinions of tourists about virtual traveling, this trend is an opportunity to find out information about the history of several places. This also distinguishes virtual traveling from streaming YouTube about a destination. On the other hand, a virtual tour cannot be used as a substitute for a walk or vacation that actually visits a place. Visuals cannot provide a sensation or feel like when tourists are actually there.

There are differences in opinions and impressions conveyed by the two sources who are tourists, resource person 1 stated that virtual traveling is only an option to fill spare time and just to get information, but for entertainment it does not meet tourist standards or criteria. In contrast to resource person 2 who considered that virtual traveling was sufficient to meet current entertainment needs. Not only being able to see the scenery, resource person 2 stated that he was better able to build communication with friends while participating in virtual traveling.

The two tourists who have different meanings still have something in common when participating in virtual traveling, namely gaining experiences from visual culture. Based on visual culture theory, Mirzoeff's concept of understanding visual culture refers to information events / events in visual form, which have elements of meaning and pleasure according to what individuals need when using and connecting with technology.

\subsection{The virtual meaning of travel for Whatravel (travel agent)}

When the Covid-19 pandemic came, one of Whatravel's efforts to stay connected with consumers was virtual traveling. With the main goal of staying connected, Whatravel has fulfilled its PR function in maintaining relationships with consumers and increasing brand awareness through virtual traveling activities.

Whatravel's virtual traveling program is one of the creations of a visual culture. Communication messages in the form of images and videos are managed and created in such a way that will then produce meaning and pleasure in relation to the needs of tourists with communication technology intermediaries. The final result issued is feedback from tourists on virtual traveling in the form of messages and impressions after participating in the activity.

\subsection{Digital age travelers: An informative society}

Digital era tourists who are literate with technology and innovations such as virtual traveling are an informative society. Based on their need for digital technology, the informative society is the one with the highest need for information and is very dependent on technology in various aspects of daily activities. Apart from informative societies, there are industrial and agrarian societies that also use technology but are not so dependent and literate with digital technology as the informative society.

\section{CONCLUSIONS}

Based on research on virtual travel, informative society becomes a modern society because of its dependence on technology. Virtual travel is a form of communication with the aim of fulfilling information and entertainment needs 
using CMC technology. An understanding of the meaning of virtual traveling based on interview results (Sinta, 2020) is a tourism activity that relies on technology that is carried out boldly. Virtual travel in its form can be divided into two, namely virtual travel and direct virtual travel. The two are only differentiated based on the form of content presented to consumers or tourists. Virtual trips are usually served with google earth, videos, or photos presented in online meeting rooms with sharing screens. The difference with live virtual trips, videos and images, and google earth become supporting documents when virtual trips take place. There are differences in the experiences obtained by the two sources who are tourists, informant 1 stated that virtual travel is only an option to fill spare time and only get information, but for entertainment it does not meet the standards or criteria of tourists. In contrast to source 2 who considered that virtual travel was sufficient to meet entertainment needs at this time. Not only being able to see the scenery, source 2 is better known for building communication with friends while on virtual trips.

Travel experiences for travel agents in the form of feedback and brand awareness of consumers or tourists on Whatravel. Communication messages in the form of images and videos that are managed and in such a way that will then produce an experience and meaning of the event related to the needs of tourists with communication technology intermediaries. Maintaining relationships and staying connected with consumers is Whatravel's goal of taking virtual trips.

\section{ACKNOWLEDGMENT}

Authors would like to give acknowledgment to all participants in this research for their cooperation during the research process.

\section{REFERENCES}

[1] Akhmad, K. A. (2015). Pemanfaatan Media Sosial bagi Pengembangan Pemasaran UMKM (Studi Deskriptif Kualitatif pada Distro di Kota Surakarta). Duta.Com, 9(September), 43-54. http://journal.stmikdb. ac.id/index.php/dutacom/article/view/17

[2] Badan Pusat Statistik. (2020). Ekspor Januari 2020 Mencapai US\$13,41 Miliar dan Impor Januari 2020 sebesar US\$14,28 Miliar. Badan Pusat Statistik, 41-42. https://www.bps.go.id/pressrelease/2020/02/17/1675/ek spor-januari-2020-mencapai-us-13-41-miliar-danimpor-januari-2020-sebesar-us-14-28-miliar.html

[3] Bimbingan, B., \& Konseling, D. A. N. (2016). Metode Penelitian Kualitatif dalam Bidang Bimbingan dan Konseling. Jurnal Fokus Konseling, 2(2). http://ejournal.stkipmpringsewu- lpg.ac.id/index.php/fokus/a

[4] Education, J. (2020). PENUNDAAN PEMBAYARAN ANGSURAN KREDIT DAMPAK COVID-2019 DI INDONESIA. 8(3), 144-155.

[5] Effendi, M. (2010). PERANAN INTERNET SEBAGAI MEDIA KOMUNIKASI. Dakwah Dan Komunikasi, 4(1).

[6] Febriana, A. I. D. (2018). Determinasi Teknologi Komunikasi Dan Tutupnya Media Sosial Path. LONTAR: Jurnal Ilmu Komunikasi, 6(2), 86. https://doi.org/10.30656/lontar.v6i2.948

[7] Harahap, J. Y. (2017). Hubungan Antara Kontrol Diri Dengan Ketergantungan Internet Di Pustaka Digital Perpustakaan Daerah Medan. JURNAL EDUKASI: Jurnal Bimbingan Konseling, 3(2), 131. https://doi.org/10.22373/je.v3i2.3091

[8] Johannes, D. T. W., \& Rasyid, U. N. (2018). Komunikasi Bisnis Pada Etnis Tionghoa Studi Kasus Di Warung Kopi Asiang, Kota Pontianak, Kalimantan Barat. Bricolage: Jurnal Magister Ilmu Komunikasi, 3(02), 118-155. https://doi.org/10.30813/bricolage. v3i02.928

[9] Kawisata, D. U. (2020). PT Kereta Api Pariwisata Luncurkan "Virtual Tours The Legend Jogja ." 9-10.

McQuail, D. (2011). Teori Komunikasi Massa Mcquail, Edisi 6 Buku 1. https://difarepositories.uin-suka.ac.id /122/1/Teori Komunikasi Masa McQuail.pdf

[10] Nugraha, A. (2020). Virtual Reality ( VR ) sebagai Media Komunikasi dalam Menangani Masalah Transportasi Perkotaan. Communication Digital, 1-4.

[11] Raco, J. (2018). Metode penelitian kualitatif: jenis, karakteristik dan keunggulannya. https://doi.org/10. 31219/osf.io/mfzuj

[12] Rakhmat, S. H. (2020). Nilai Budaya Khalayak Digital dalam Komentar pada Konten Dakwah di Instagram Hanan_Attaki. Ilmu Dakwah Dan Ilmu Komunikasi, 2(3), 1689-1699. https://doi.org/10.1017/ CBO9781107415324.004

[13] Rijali, A. (2019). Analisis Data Kualitatif. Alhadharah: Jurnal Ilmu Dakwah, 17(33), 81. https:// doi.org/10.18592/alhadharah.v17i33.2374

[14] Rio, A. O. (2011). Kajian Budaya Visual Dalam Ilmu Komunikasi : Ilmu Komunikasi, 195-206.

[15] Rizal, J. G. (2020). Pandemi Covid-19, apa saja dampak pada sektor ketenagakerjaan Indonesia? 
Kompas.Com, 1-8. https://www.kompas.com/tren/read/ 2020/08/11/102500165/pandemi-covid-19-apa-sajadampak-pada-sektor-ketenagakerjaan-indonesia?page $=$ all

[16] Saurik, H. T. T., Purwanto, D. D., \& Hadikusuma, J. I. (2019). Teknologi Virtual Reality untuk Media Informasi Kampus. Jurnal Teknologi Informasi Dan Ilmu Komputer, 6(1), 71. https://doi.org/10.25126/ jtiik.2019611238

[17] Sundar, S. S. (2015). The Handbook of the Psychology of Communication Technology. In Journal of Visual Languages \& Computing (Issue 3). https://www.m-culture.go.th/mculture_th/download/ king9/Glossary_about_HM_King_Bhumibol_Adulyade j's_Funeral.pdf

[18] Supriyanto, Y. (2020). Virtual Traveling: Yuk Keliling Dunia secara Online. Traveling Bisnis, 1-12.

[19] Talika, F. T. (2016). Manfaat Internet Sebagai Media Komunikasi Bagi Remaja Di Desa Air Mangga Kecamatan Laiwui Kabupaten Halmahera Selatan. EJournal, V(1), 1-6.

[20] Tarifu, L. dkk. (2019). Komunikasi, Media, dan New Media dalam Pembangunan Daerah. In Journal of Chemical Information and Modeling (Vol. 53, Issue 9). https://doi.org/10.1017/CBO9781107415324.004

[21] Wardhana, I. W. (2020). Covid-19 Tekan Pertumbuhan Ekonomi Indonesia Triwulan II 2020. News.Detik.Com, 225520. https://news.detik.com/ kolom/d-5031726/work-from-home-selamanya

[22] Wibowo, E. A. S. dan R. (2018). Model dan Pola Computer Mediated Communication Pengguna Remaja Instagram dan Pembentukan Budaya Visual. Jurnal Ilmu Komunikasi, 16(2), 147-157. http://jurnal.upnyk.ac.id/ index.php/komunikasi/article/view/2698/2258

[23] Wijaya, H. (2013). Metode Penelitian Pendidikan Teologi. E-Modul, August 2013, 1-8. 